\title{
RENEWAL OF CRIMINAL LAW: DRAFT OF INDONESIAN CRIMINAL CODE, SPIRIT OF CODIFICATION AND ITS EFFECTS ON LAW HARMONIZATION
}

\author{
Rachel Octora \\ * Dosen Fakultas Hukum Universitas Kristen Maranatha, Bandung \\ Korespondensi:octorael@ hotmail.com, sarilimbert@gmail.com \\ Naskah dikirim: 31 Mei 2016 \\ Naskah diterima untuk diterbitkan: 2Agustus 2016
}

\begin{abstract}
Law-making process needs to be observed by public, and also by legal scholar, the purpose is to avoid inconsistency between new regulation and existing regulation. This paper will describe about Draft of Indonesian Criminal Code. Countries that use Civil Law System, especially in criminal law, principle of legality becomes the most important principle. Indonesia currently designing recodification of the Criminal Code and aspire to have their very own criminal codification. Draft of Indonesian Criminal Code is now still waiting to be enacted. It will potentially cause disharmony in the implementation process, because of the probability that one criminal act regulated by more than one regulation. Based on this research, Will reach the conclusions those criminal acts which have been regulated in another regulation outside the code, do not need to be re-regulated inside the code because it will potentially overlapping and confusing in the implementation process. If the Draft of Indonesian Criminal Code finally enacted, the way to harmonizing regulations inside and outside the code has to be based on transitional regulation inside the Code which states the applicable regulation is one that causing benefit for the offender.
\end{abstract}

Keywords: Legality principle, codification, draft of Indonesia Criminal Code, harmonization of regulation.

\begin{abstract}
Abstrak
Proses penyusunan peraturan perundang-undangan perlu mendapatkan perhatian dari masyarakat dan juga akademisi hukum. Tujuannya adalah untuk menghindari ketidakkonsistenan antara aturan baru dengan aturan yang sudah ada. Tulisan ini akan membahas mengenai Rancangan Kitab Undang-undang Hukum Pidana. Negara yang menganut tradisi hukum Civil Law yang menempatkan undang-undang sebagai sumber hukum utama, asas legalitas menjadi asas yang paling dikedepankan dalam hukum pidana. Negara Indonesia bercita-cita memiliki kodifikasi hukum pidana nasional. Rancangan KUHP masih dimatangkan sampai saat ini dan menunggu proses pengesahan. Hal menarik yang layak dibahas adalah di dalam RKUHP termuat berbagai jenis tindak pidana yang sebenarnya telah diatur di dalam Undang-undang di luar KUHP, berpotensi menimbulkan ketidakharmonisan di dalam penerapan aturan karena sangat mungkin terjadi adanya satu peristiwa hukum yang diatur oleh lebih dari satu aturan. Berdasarkan penelitian ini dapat disimpulkan bahwa tindak pidana yang sudah diatur di dalam undang-undang tersendiri tidak perlu diatur kembali di dalam RKUHP karena akan menimbulkan tumpang tindih aturan dan kebingungan di dalam proses penerapan hukum. Apabila RKUHP akhirnya disahkan, cara mengharmonisasikan aturan dalam RKUHP dengan aturan yang sudah ada sebelumnya adalah dengan berpedoman pada aturan peralihan di dalam RKUHP yang menyatakan, aturan yang akan diterapkan adalah yang menguntungkan bagi pelaku.
\end{abstract}

Kata kunci : asas legalitas, kodifikasi, RKUHP, harmonisasi aturan. 


\section{Introduction}

Each country has its own legal system. It will influence the State's perspective on the meaning of law. Difference of legal system will also bring difference in State's perspective about what law is, what prevailing law is, and how law be enforced. Indonesia is a state with Civil Law System. Civil Law System placing the written regulation as the primary source of law and codified statutes predominate. It's different from Common Law System, whereas judge made law is the primary source of law. The court's decision will bind into other similar cases within the same jurisdiction. In common Law System, judges have important roles in creating new law.

As has been mentioned above, State with Civil Law System placing the written regulation as the primary source of law. The logical consequence is states with Civil Law System have more spirit and enthusiasm in making written regulations. Law-making process is a part of Legislative's routine.

For example, Indonesia recognized the terminology "National Legislation Program" (prolegnas) which is a program held by the government and conducted by Indonesian Legislative Assembly in performing its legislative function in forming and creating laws (acts). The purpose of the law to fulfill certain justice, legal certainty and benefit to society are often considered to be fulfilled by the existence of complete and comprehensive written rules.

That was a short review about the influence of Civil Law System on Law-making process in Indonesia. Civil Law System also strictly makes difference between private law and public law. Private law regulates legal relationship between persons, in which law enforcement is based on those parties' interest and initiative. Public law regulates relationship between citizens and state. The regulations are about public interest. State intervene law enforcement.

Criminal law is a part of public law. Criminal Law (substantive) can be defined as rules that regulate action of legal subject, which establish the rights and obligations, what individuals may or may not do, and also punishment for the violation. Punishment in criminal law will bring suffer for the offenders, so that the execution must be based on written regulations. It means, in criminal law, legality principle is absolutely prevails. The principle of legality is clearly stated in Article 1 ( 1 ) of the Criminal Code that is currently prevail. In the process, the Draft of Criminal Code provides the possibility of entry into force of the law who live in the community as a basis for criminal prosecution. In terms of the rule of law is considered less guarantee of legal certainty. Basicly, it is contrary to the principle of legality and purpose of the rule of law that should provide certainty and enactment in general (national). ${ }^{1}$ It is that one of the triggers polemic in the plan to implement the new Criminal Code. Back to

\footnotetext{
${ }^{1}$ Ruslan Renggong, Reform of Criminal Law and Implications for Law Enforcement in Indonesia, “Journal of Studies in Social Sciences", Vol. 8, No. 2, (2014), p. 293.
} 
the rule of law discussed above. The renewal of the Criminal Code towards the availability of a complete and comprehensive law, are a way that the law can be accessed. The accessibility of laws and regulations are parts of access to justice concept. The concept relating very close to the rule of law, when we talk about access to justice we assume that the rule of law also exist. Rule of law is for the UN, the Secretary-General defines as

a principle of governance in which all persons, institutions and entities, public and private, including the State itself, are accountable to laws that are publicly promulgated, equally enforced and independently adjudicated, and which are consistent with international human rights norms and standards. It requires, as well, measures to ensure adherence to the principles of supremacy of law, equality before the law, accountability to the law, fairness in the application of the law, separation of powers, participation in decision-making, legal certainty, avoidance of arbitrariness and procedural and legal transparency. ${ }^{2}$

The definition above in line with the purpose of the renewal of the Criminal Code, besides to reform and review the key issues in criminal law itself, there are the formulation of a prohibited act (criminal act), the formulation of criminal liability (criminal responsibility) and the formulation of sanctions in the form of criminal punishment or treatment, it is also trying to optimally provide a philosophical foundation to the nature of the Criminal Code so that more meaningful in terms of human values (humanitarian values) both with regard to criminal (offender) or victim (victim). ${ }^{3}$ The principle of such a renewal must be accommodated by a legal framework. The legal framework in which is the elements of access to justice, are the laws and regulations establish citizen's rights and duties, and provide citizens with mechanisms to solve their justice problems. ${ }^{4}$

In writers sight that is a matter of the availability of regulation and legal certainty. It is the main issues accommodated in the discussion of this paper, the potentially overlapping rules between renewal of criminal code and the existence law outside the code. As it can be confusing about which available laws are appropriate and can be used in a criminal case, and it also interfere with legal certainty. It is obvious that the conflict between regulations is a barrier to have the access to justice.

Given that, Indonesia is a state of law which is mentioned in Article 1 paragraph (3) of the Constitution of the Republic of Indonesia (UUD 1945).

\footnotetext{
${ }^{2}$ United Nations Rule of Law, "Report of the Secretary-General: The rule of Law and Transitional Justice in Conflict and Post-Conflict Societies,"http://www.unrol.org/article.aspx?article_id=, accessed October 11, 2015 18:39

${ }^{3}$ National Law Development Agency of the Ministry of Justice and Human Rights of the Republic of Indonesia, Academic Draft of the Book of Criminal Law Draft (KUHP) (Jakarta: National Law Development Agency, March,2015), p. 23.

${ }^{4}$ American Bar Association, Access to Justice Assessment for Indonesia South Sulawesi Province (Washington D. C.: American Bar Association, 2012), p. 1.
} 
Consequently in rulling the government and running the law enforcement should be based on law, and the law is the written law.

Written regulation can be seen in two forms, codified and uncodified. Indonesia criminal code (known as Kitab Undang-undang Hukum Pidana / KUHP) is primary legal source for criminal law in Indonesia. KUHP divided into 3 parts. The first part, concerning General Provisions, the second part concerning Crimes, and the third part concerning Misdemeanors.

KUHP that now prevailed is colonialism inheritance, product of Dutch government enacted in Indonesia. In Netherland, was named Wetboek van Strafrecht $(W v S)$. Rules and provisions inside KUHP do not sufficient with today's conditions and society's demands. Law, especially in written form, will tends to be left by society's change and development.

The process of Criminal Code renewal, at the beginning should admit only based on the desire to replace the colonial characteristics of the current Criminal Code. The renewal process is done partially and its not thorough therefore could not solve new problems. The concequence are many laws and regulations that are sectoral and are not consolidated in the Book of the National Criminal Law. However, afterall the development of the Criminal Code changed towards a more advanced and targeted goals. The development based on Pancasila and the Constitution (UUD 1945), as well as to respect and uphold human rights. In addition, the purpose of the establishment of the National Criminal Code is to adapt the national legal politics, condition, and development of the life of the nation. Therfore the reason is not solely to replace the Code of Criminal Law (Wetboek van Strafrecht) as a product of the colonial era. ${ }^{5}$

Based on some considerations, such as philosophical, juridical, and sociological considerations, Indonesia formulates National Criminal Code. Spirit of the law makers to have new National Criminal Code must be highly appreciated, although in the process of formulation of new KUHP, faces some problems and controversies. It caused by some rules that supposed to be inconsistence with fundamental legal principles.

This paper would like to explain about "Renewal of Criminal Law: Draft of Indonesian Criminal Code, Spirit of Codification and Its Effects on Law Harmonization". The word "harmonization" becomes an important word, because some of criminal misconduct has been regulated in other regulations outside the code, like corruption, terrorism, violation of human rights, pornography, narcotic and psychotropic, human trafficking, and money laundering.

When the Draft of Indonesia Criminal Code is legally prevailed, overlapping regulations from two sources toward the same legal case will be a problem that needs to be concern. Therfore this paper will compare the draft of Indonesia Criminal Code and specific prevailing regulations outside the code, to understand about potentialy conlict between regulations.

5 ELSAM, Tinjauan Umum terhadap Rancangan Kitab Undang-undang Hukum Pidana (KUHP), (Jakarta: ELSAM, 2005), pp. 5-6. 


\section{Problems Statement}

Based on the backgrounds, we like to state and define the problems into two specific questions below:

1. Do the lawmakers need to re-regulate criminal act that has been regulated outside the code?

2. If the Draft of Indonesia Criminal Code be legally prevailed, and it consist of regulations concerning those criminal acts, how to harmonize new regulations with existing regulation?

\section{Research Methods}

1. Research method and approaches

This research is done by normative juridical method. That means the study of the research object is done in normative fields. Johnny Ibrahim explained that normative juridical method is a scientific research procedure to find the truth based on legal science logical from normative sides. ${ }^{6}$ Data that will be analyzed is connected with regulations prevailed. ${ }^{7}$ Soerjono Soekanto talks about data that will be used are secondary data such as: ${ }^{8}$

a. Primary legal materials such as regulations, judge made law, and any other legal sources that related to the problems.

b. Secondary legal materials such as scientific articles in criminal law, law journal, etc.

c. Tertiary legal materials such as law dictionary and any other relevant literatures.

\section{Research Specification}

This research is descriptive analytical research, which describes and gives explanations about facts and accurate analysis on prevailing law, related with relevance legal theories on harmonization between legal substance in Draft of Indonesia Criminal Code and other regulations outside the code. This research is directed to give answer of the question, "Is it urgent to regulate all criminal actions in KUHP?"

3. Method of Data Collecting

Data collecting process is done by literature study, to collect legal theories, legal principles, and legal norms in written regulations.

6 Johnny Ibrahim, Teori dan Metodologi Penelitian Hukum Normatif, (Malang: Bayumedia Publishing, 2006), p. 57.

7 Ronny Hanitijo Soemitro, Metodologi Penelitian Hukum, (Jakarta:Ghalia Indonesia, 1982), p.10.

8 Soerjono Soekanto, Pengantar Penelitian Hukum, (Jakarta: UI Press, 1986), p.52. 


\section{Literature Review and Explanation}

\section{Indonesia Criminal Code as a Codification}

Criminal law has to be applied and enforced based on legality principles. The principle of Nullum delictum noella poena sine praevia lege poenali, has been listed in Article 1 paragraph (1) of the Criminal Code, "No act shall be punished unless by virtue of a prior statutory penal provision". That means, no act prohibited and punishable by advance if it is not stated in the rules of law ${ }^{12}$, furthermore also contain no analogies principle in determine the existence of a criminal act, and principle no retroactive. ${ }^{13}$ The existence of a codification is very helpful for judges in law enforcement process. ${ }^{14}$ Although, it is very often judges then trapped into shallow written regulation enforcement, rather then law and justice enforcement. Indonesia Criminal Code is a general source of criminal law. It was prevailed in Indonesia based on concordance principle. Legal basis of prevailing Netherland Criminal Code in Indonesia is Law Number 1 Year 1946. First Book - Article 103 Indonesia Criminal Code regulates:

The provisions of the first eight Chapters of this Book shall also apply to facts on which other statutory provisions impose punishment, unless determined otherwise by statute.

The provision above indicates the existence of other statutory provisions. It means the lawmakers on that time were totally aware that it was impossible to regulate every criminal act in one codification. Law has to be developed to accommodate society's change, but in contrary, it will be impossible to always make changes or add new provision into a codification if new crimes happen.

A codification is only able to accommodate and regulate crimes that already exist before. Indonesia Criminal Code is also only able to accommodate and regulate crimes that already exist now. A codification can not anticipate development of crimes that possibly develop in the future.

That means, spirit to form national law is not identically similar as spirit of making new codification. In our opinion, renewal of criminal law must be done to reach purposes of law. Law can reach its' purposes if it consistently enforced. Legal substances in statutes are only one of several important factors that have to be noticed in law enforcement process. Law enforcement can not be limited in narrow meaning as statute enforcement. Criminal law enforcement has to be done by certain criminal justice policy, which has been

12 Although there are some exception to the principle of legality in the case of not an ordinary crimes.

${ }^{13}$ Renggong, op. cit., p 292.

14 In order not disturbed the criminal justice system, the formulation of Indonesian criminal law by Indonesia for the Indonesian people, conducted by means of a re - codification of the WvS 1918 ( as amended up to 1993 ). Mardjono Reksodiputro, "Direction of Criminal Law in Draft of Criminal Code," in Aligning Legal Reform, ed. National Law Commission (Jakarta: the National Law Commission, 2009), p 34 . 
arranged and designed by the government. Therefore, the government should establish what kind of legal policy and criminal policy to be applied, before enacted a new Criminal Code

Criminal Policy is rational efforts to overcome crimes. Criminal policy is a part of legal policy (law enforcement policy). They are part of social policy, which means society's effort or state's effort to improve societies' welfare. ${ }^{15}$

As effort to overcome crimes, criminal policy can be manifested in several forms. The first form is the repressive nature by enforce the punishment, which is often referred to as the criminal justice system. In this case also covers the process of criminalization. The second, form of prevention efforts without punishment, and the third is to leverage the efforts of the formation of public opinion about crime and dissemination law through the mass media broadly. At the end, statute (in which criminal policy implied), will contribute and become inseparable part from law enforcement process to reach the purpose of the law. Every statute have to show philosophy, missions, which purpose are to certain legal order, legal certainty, justice, and bring effects to social, economy and political aspect. ${ }^{16}$

\section{Special Criminal Law and General Criminal Law}

Special criminal law is criminal law which be applied for specific group of people, and it also related with specific criminal deeds. In specific criminal law, there are provisions that deviate from general criminal law, which concern on specific deeds.

Statute which regulates specific criminal action usually has more detail provisions. Those statutes may be formed in criminal law statutes or may be formed in other sectoral statutes, in which we can find provisions about criminal punishment. In terms of the statutes are the criminal laws statutes, (such as the law of corruption, money laundering, human trafficking, terrorism, and so on), the law not only set any offense defined as a criminal offense, but also regulates the crime prevention policies and monitoring compliance. In addition it also regulates procedural law, ranging from the investigation stage to the stage of the examination in the courtroom.

In sectoral statute, the provisions systematically arranged from general matters to specific matters. At first, there are articles about definition of some terminology, and then there are provisions regarding the main matter (for example, about environment, copyright, competition, etc). Then, there are provisions regarding administrative sanction. Regulation concerning criminal deeds usually placed at the end. It means, in sectoral statute, provisions regarding criminal acts is a supporting part for law enforcement. In the development, this concept recognized as administrative penal law.

${ }^{15}$ Muladi, et.al., "Bunga Rampai Hukum Pidana," (Bandung: Alumni, 2007), p.1.

16 Romli Atmasasmita, "Politik Hukum Pidana dalam Pembangunan Nasional," in Hukum Pidana Indonesia-Perkembangan dan Pembaharuan, ed. Sigid Suseno, Nella Sumika Putri (Bandung: Remaja Rosdakarya,2013), p. 128. 


\section{Comparison on Regulation Regarding Specific Criminal Acts in Statutes and Regulation Regarding Specific Criminal Acts in Draft of Indonesia Criminal Code.}

In this section, the author will present a comparison between the settings of some specific criminal offense outside the Criminal Code with the settings on RKUHP. The authors did not perform a comparison against all criminal acts specifically regulated outside the Criminal Code and would be set in RKUHP. The author will take some kind of criminal offense, namely representing the offenses stipulated in the Criminal Code outside the Criminal Code (Corruption, Terrorism, Money Laundering), and that represents a criminal act is set in the sectoral laws particular (which are administrative penal law), including Environmental Crime, Copyright and Trademark and Monopolistic Practices and Unfair Business Competition.

By doing this comparison, is expected to be known whether RKUHP can manage to cover the entire specific criminal offense, or settings outside of codification is still needed. The following tables illustrate the comparison.

Table 1.

Comparison on Regulation Regarding Specific Criminal Acts in Statutes and Regulation Regarding Specific Criminal Acts in Draft of Indonesia Criminal Code

\begin{tabular}{|c|c|c|c|c|}
\hline No. & Crimes & $\begin{array}{l}\text { Regulations outside } \\
\text { Codification }\end{array}$ & $\begin{array}{l}\text { Substance in } \\
\text { Codification }\end{array}$ & Results of Comparison \\
\hline 1 & Terrorism & $\begin{array}{l}\text { Law No.15 Year } 2003 \text { on } \\
\text { Determination of PERPU } \\
\text { No.1 Year } 2002 \text {, on } \\
\text { Eradication of Terrorism } \\
\text { Regulated matters: } \\
\text { - definition of terrorism } \\
\text { - scope of regulation } \\
\text { - formulation of criminal } \\
\text { action's elements } \\
\text { - related crimes with } \\
\text { terrorism funding } \\
\text { - procedural law } \\
\text { - International } \\
\text { Cooperation } \\
\text { Regulated Actions: } \\
\text { - Terrorism in general } \\
\text { meaning } \\
\text { - Acts which } \\
\text { intentionally makes } \\
\text { terror ambience. } \\
\text { - Similar Acts with } \\
\text { terrorism } \\
\text { - Criminal actions on } \\
\text { goods that suspiciously } \\
\text { used to do terrorism } \\
\text { - Terrorism with } \\
\text { chemical materials } \\
\text { - Terrorism Funding }\end{array}$ & $\begin{array}{l}\text { Article 242- } 251 \\
\text { Regulated Actions: } \\
\text { - Terrorism } \\
\text { - Acts which } \\
\text { intentionally makes } \\
\text { terror ambience. } \\
\text { - Terrorism with } \\
\text { chemical materials }\end{array}$ & $\begin{array}{l}\text { Punishment in Law No. } \\
\text { UU } 15 \text { / 03: } \\
\text { death penalty, or lifetime } \\
\text { imprisonment or } \\
\text { imprisonment between } 4 \\
\text { - } 20 \text { years. } \\
\text { Punishment on } \\
\text { Codification Draft : } \\
\text { Death penalty, or lifetime } \\
\text { imprisonment or } \\
\text { imprisonment between } 5 \\
\text { - } 20 \text { years. }\end{array}$ \\
\hline $1 \mathrm{a}$ & $\begin{array}{l}\text { Terrorism } \\
\text { Funding }\end{array}$ & $\begin{array}{l}\text { Law No. } 9 \text { Year } 2013 \text { on } \\
\text { Prevention and }\end{array}$ & $\begin{array}{l}\text { The regulated matters } \\
\text { are only formulation of }\end{array}$ & $\begin{array}{l}\text { Punishment determined } \\
\text { in Code, between } 3-15\end{array}$ \\
\hline
\end{tabular}




\begin{tabular}{|c|c|c|c|c|}
\hline & & $\begin{array}{l}\text { Eradication Terrorism } \\
\text { Funding } \\
\text { - definition of terrorism } \\
\text { funding } \\
\text { - scope of regulation } \\
\text { - formulation of criminal } \\
\text { action's elements } \\
\text { - related crimes with } \\
\text { terrorism funding } \\
\text { - prevention actions } \\
\text { - blockading } \\
\text { - procedural law } \\
\text { - Cooperation in } \\
\text { preventing and } \\
\text { eradicating terrorism } \\
\text { funding } \\
\text { Regulated Actions: } \\
\text { - Terrorism Funding } \\
\text { - Attemption } \\
\text { - Conspiracy and } \\
\text { Terorisme Funding } \\
\text { - Provoke others to do } \\
\text { terrorism funding }\end{array}$ & $\begin{array}{l}\text { criminal action's } \\
\text { elements and the } \\
\text { criminal punishment. } \\
\text { Regulated actions: } \\
\text { - terrorism funding } \\
\text { - terrorism with } \\
\text { chemical materials } \\
\text { funding } \\
\text { - Provoke others to do } \\
\text { terrorism funding } \\
\text { - Facilitating others to } \\
\text { do terrorism funding, } \\
\text { - Doing terrors with } \\
\text { aviator means }\end{array}$ & $\begin{array}{l}\text { years imprisonment. In } \\
\text { Law No.9/ } 2013 \text { only said } \\
\text { maximum imprisonment } \\
\text { of } 15 \text { years. } \\
\text { In Codification, regulated } \\
\text { terrorism with chemical } \\
\text { materials funding (Article } \\
246 \text { ). } \\
\text { Provoke others to do } \\
\text { terrorism funding: } \\
\text { Law } 9 / 13 \text { : lifetime } \\
\text { imprisonment or } \\
\text { maximum imprisonment } \\
\text { of } 20 \text { years. } \\
\text { In Codification: } \\
\text { death penalty, lifetime } \\
\text { imprisonment or } \\
\text { minimum imprisonment } \\
\text { of } 5 \text { years and maximum } \\
\text { imprisonment of } 20 \text { years } \\
\text { Both regulations decide } \\
\text { different punishment for } \\
\text { the same criminal } \\
\text { actions. }\end{array}$ \\
\hline 2 & \begin{tabular}{|l|} 
Criminal \\
Actions \\
against \\
Environm \\
ent
\end{tabular} & $\begin{array}{l}\text { Law No.32 Year } 2009 \text { on } \\
\text { Environmental Protection } \\
\text { and Management. } \\
\text { This statute regulates } \\
\text { environmental matters } \\
\text { comprehensively, and } \\
\text { consists of penal } \\
\text { punishment for actions } \\
\text { such as: } \\
\text { - Violation of the } \\
\text { environmental quality } \\
\text { standard } \\
\text { - distribution of genetic } \\
\text { changes products } \\
\text { unlawfully } \\
\text { - management of } \\
\text { hazardous and toxic } \\
\text { materials in } \\
\text { environmental } \\
\text { damaging manner } \\
\text { - violation of arranging } \\
\text { process of AMDAL- } \\
\text { UPL-UKL } \\
\text { - Criminal deeds done by } \\
\text { the officials. }\end{array}$ & $\begin{array}{l}\text { Article 384-389: } \\
\text { regulates causing death } \\
\text { actions which done by } \\
\text { intention or negligence, } \\
\text { such as: } \\
\text { - environment } \\
\text { polluting } \\
\text { - putting dangerous } \\
\text { materials into water } \\
\text { - putting dangerous } \\
\text { materials into soil, air } \\
\text {, and surface water }\end{array}$ & $\begin{array}{l}\text { Formulation of criminal } \\
\text { action's elements in } \\
\text { codification is general. } \\
\text { Law No.32 Year } 2009 \\
\text { formulates criminal } \\
\text { action's elements more } \\
\text { specifically. } \\
\text { It will bring difficulties to } \\
\text { apply the provision as } \\
\text { there will always be } \\
\text { possibilities for us to find } \\
\text { cases which comply with } \\
\text { more than one provision. } \\
\text { For example, cases of } \\
\text { mismanagement of } \\
\text { hazardous and toxic } \\
\text { materials also comply } \\
\text { with provision regarding } \\
\text { commiting action causing } \\
\text { environmental pollution } \\
\text { or damages. } \\
\text { In such a case, confusions } \\
\text { come as new regulation } \\
\text { (lex posterior), is a } \\
\text { general regulation (lex } \\
\text { generalis). }\end{array}$ \\
\hline $3 a$ & Copyright & $\begin{array}{l}\text { Law No. } 19 / 2002 \text { on } \\
\text { Copyright regulates } \\
\text { punishable deeds such as: } \\
\text { - deliberately broadcasts, }\end{array}$ & $\begin{array}{l}\text { Article } 626 \text { : } \\
\text { - counterfeiting name } \\
\text { of copyright's creator } \\
\text { - selling goods with }\end{array}$ & $\begin{array}{l}\text { Law on Copyright } \\
\text { regulates violations of } \\
\text { copyright in detail, but } \\
\text { the Code regulates it }\end{array}$ \\
\hline
\end{tabular}




\begin{tabular}{|c|c|c|c|c|}
\hline & & $\begin{array}{l}\text { exhibits, distributes, or } \\
\text { sells to the public a } \\
\text { work or goods resulting } \\
\text { from an infringement of } \\
\text { copyright or related } \\
\text { rights } \\
\text { - publication of any work } \\
\text { which is contrary to } \\
\text { government policy in } \\
\text { the field of religion, } \\
\text { defence and state } \\
\text { security, morals and } \\
\text { public order. } \\
\text { - violation to the } \\
\text { provisions regarding } \\
\text { right of photographic } \\
\text { works } \\
\text { - violation to the } \\
\text { provisions regarding } \\
\text { moral right } \\
\text { - damaging, destroying } \\
\text { or making malfunction } \\
\text { of technological control } \\
\text { measure } \\
\text { - Violation to the related } \\
\text { rights. }\end{array}$ & $\begin{array}{l}\text { counterfeited } \\
\text { copyright's creator } \\
\text { name }\end{array}$ & $\begin{array}{l}\text { generally. } \\
\text { The punishment for the } \\
\text { violations is } 4 \text { years } \\
\text { imprisonment or fine in } \\
\text { IV category. } \\
\text { In Law No. 19/2002 on } \\
\text { Copyright, there are } \\
\text { several kinds of } \\
\text { punishment, based on } \\
\text { specific criminal deeds } \\
\text { that done by the offender. } \\
\text { For deliberately } \\
\text { broadcasts, exhibits, } \\
\text { distributes, or sells to the } \\
\text { public a work or goods } \\
\text { resulting from an } \\
\text { infringement of copyright } \\
\text { or related rights, will be } \\
\text { punished by } \\
\text { imprisonment of } 1 \text { month } \\
-7 \text { years. Fine, } 1 \text { million } \\
\text { rupiah - } 5 \text { billion rupiah. }\end{array}$ \\
\hline $3 b$. & Trademark & $\begin{array}{l}\text { Law No. } 15 \text { Year } 2001 \text { on } \\
\text { Trademark, regulates } \\
\text { punishable deeds such as: } \\
\text { - deliberately and } \\
\text { without right uses a } \\
\text { mark which is similar } \\
\text { in its entirety to a } \\
\text { registered mark of } \\
\text { another party for the } \\
\text { same kind of goods } \\
\text { and/or services } \\
\text { produced and/or traded } \\
\text { - deliberately and } \\
\text { without right uses a } \\
\text { mark which is similar } \\
\text { in its essential part to a } \\
\text { registered mark of } \\
\text { another party for the } \\
\text { same kind of goods } \\
\text { and/or services } \\
\text { produced and/or traded } \\
\text { - deliberately and } \\
\text { without right uses a } \\
\text { mark which is similar } \\
\text { in its entirety to a } \\
\text { geographical indication } \\
\text { of another party for the } \\
\text { same kind of registered } \\
\text { goods } \\
\text { - Trades goods and/or } \\
\text { services that are known } \\
\text { or shall be known as } \\
\text { goods and/or services } \\
\text { resulted from the } \\
\text { infringement. }\end{array}$ & $\begin{array}{l}\text { Article } 627 \\
\text { Distribute, or sells to } \\
\text { the public, goods with } \\
\text { counterfeited } \\
\text { trademarks. }\end{array}$ & $\begin{array}{l}\text { Codification generally } \\
\text { regulates violation of } \\
\text { trademark. The } \\
\text { punishment shall be } \\
\text { imprisonment for } \\
\text { maximum } 5 \text { years and/ or } \\
\text { fine for maximum } \\
\text { amount one billion } \\
\text { rupiah. } \\
\text { In Law No. } 15 \text { Year } 2001 \\
\text { on Trademark, the } \\
\text { criminal actions are } \\
\text { classified as crime which } \\
\text { can only be prosecuted } \\
\text { upon complaint, but in } \\
\text { the Code, it's classified } \\
\text { as ordinary criminal } \\
\text { actions. }\end{array}$ \\
\hline
\end{tabular}




\begin{tabular}{|c|c|c|c|c|}
\hline 4 & $\begin{array}{l}\text { Unfair } \\
\text { Business } \\
\text { Competiti } \\
\text { on }\end{array}$ & $\begin{array}{l}\text { Law No. } 5 \text { Year } 1999 \\
\text { Concerning } \\
\text { the Ban on Monopolistic } \\
\text { Practices and Unfair } \\
\text { Business Competition } \\
\text { regulates punishable } \\
\text { deeds. The deeds are } \\
\text { classified into prohibited } \\
\text { activities and prohibited } \\
\text { agreement. } \\
\text { The punishment shall be } \\
\text { imprisonment as a } \\
\text { replacement of a fine, } \\
\text { from } 1 \text { until } 100 \text { billion } \\
\text { rupiah. }\end{array}$ & $\begin{array}{l}\text { Article } 630 \text { regulates } \\
\text { unfair business } \\
\text { competition which can } \\
\text { harm the competitors. } \\
\text { The punishment shall } \\
\text { be imprisonment for } \\
\text { maximum } 4 \text { years or } \\
\text { fine in maximum } \\
\text { amount as classified in } \\
\text { the IV category. }\end{array}$ & $\begin{array}{l}\text { Same as other provisions, } \\
\text { Article } 630 \text { also } \\
\text { formulated generally. } \\
\text { Every kind of actions that } \\
\text { can harm business } \\
\text { competitors shallbe } \\
\text { punished. }\end{array}$ \\
\hline 5 & Corruption & $\begin{array}{l}\text { Law No. } 31 \text { Year } 1999 \text { as } \\
\text { amended with Law No. } \\
20 \text { Year } 2001 \text { on } \\
\text { Corruption Eradication } \\
\text { regulates punishable } \\
\text { criminal deeds such as: } \\
\text { - Unlawful actions that } \\
\text { cause loses to the state } \\
\text { finance or economy } \\
\text { - The authority abuses } \\
\text { that cause loses to the } \\
\text { state finance or } \\
\text { economy } \\
\text { - Graft } \\
\text { - Gratification. }\end{array}$ & $\begin{array}{l}\text { Article 688-702: } \\
\text { Article 688-695 } \\
\text { regulate graft actions } \\
\text { with many kinds of } \\
\text { criminal actions' } \\
\text { elements. } \\
\text { Article 696-699 } \\
\text { regulate embezzlement } \\
\text { and authority abuses } \\
\text { done by public } \\
\text { officials. } \\
\text { Article700-701 regulate } \\
\text { gratification. }\end{array}$ & $\begin{array}{l}\text { Provisions in Law No. } 31 \\
\text { Year } 1999 \text { as amended } \\
\text { with Law No. } 20 \text { Year } \\
2001 \text { on Corruption } \\
\text { Eradication are more } \\
\text { comprehensive, and } \\
\text { completed with specific } \\
\text { procedural law. }\end{array}$ \\
\hline 6 & $\begin{array}{l}\text { Money } \\
\text { Launderin } \\
\mathrm{g}\end{array}$ & $\begin{array}{l}\text { Money Laundering } \\
\text { regulated by Law No. } 8 \\
\text { Year } 2010 \text { on } \\
\text { Countermeasure and } \\
\text { Eradication of Money } \\
\text { Laundering. } \\
\text { The provisions are: } \\
\text { Article 3: Money } \\
\text { Laundering shall be } \\
\text { punished with maximum } \\
\text { of imprisonment of } 20 \\
\text { years and fine for } \\
\text { maximum amount of } 10 \\
\text { Billion Rupiah. } \\
\text { Article5: Passive offender } \\
\text { shall be punished with } \\
\text { maximum } 5 \text { years of } \\
\text { imprisonment and fine } \\
\text { for maximum amount of } 1 \\
\text { Billion Rupiah. } \\
\text { Corporations also can be } \\
\text { punished with fine for } \\
\text { maximum amount of } 100 \\
\text { Billion Rupiah and much } \\
\text { kind of additional } \\
\text { punishments. }\end{array}$ & $\begin{array}{l}\text { Article 747-752: } \\
\text { Money Laundering } \\
\text { shall be punished with } \\
\text { maximum of } \\
\text { imprisonment of } 20 \\
\text { years and fine for } \\
\text { maximum amount as } \\
\text { classified in the V } \\
\text { category. } \\
\text { Passive offender shall } \\
\text { be punished with } \\
\text { maximum } 5 \text { years of } \\
\text { imprisonment and fine } \\
\text { for maximum amount } \\
\text { as classified in the IV } \\
\text { category. } \\
\text { Corporations also can } \\
\text { be punished with fine } \\
\text { for maximum amount } \\
\text { as classified in the IV } \\
\text { category many kind of } \\
\text { additional punishments. }\end{array}$ & $\begin{array}{l}\text { Law No. } 8 \text { Year } 2010 \text { on } \\
\text { Countermeasure and } \\
\text { Eradication of Money } \\
\text { Laundering, has } \\
\text { morecomprehensive } \\
\text { regulations. It doesn't } \\
\text { only regulate the actions, } \\
\text { but also procedural } \\
\text { provisions, reporting } \\
\text { mechanism and } \\
\text { compliance supervision. } \\
\text { Report can be done by } \\
\text { financial service } \\
\text { providers. } \\
\text { In this statute, also } \\
\text { regulated about role of } \\
\text { Financial Transaction } \\
\text { Report and Analysis } \\
\text { Center, in counterfeiting } \\
\text { and eradicating money } \\
\text { laundering. }\end{array}$ \\
\hline
\end{tabular}




\section{Analysis on Regulations Regarding Special Crimes in Codification}

Barda Nawawi Arief defines renewal of criminal law as a part of policy to renew legal substance, to improve effectiveness of law enforcement. It's also a rational effort to remove crimes, to protect the society. It's also a rational effort to support national's purpose (social defence and social welfare), process of re-orientation and re-evaluation of fundamental ideas or socio-philosophical values, socio-politic and socio-cultural that become base of criminal policy and criminal law enforcement policy. ${ }^{17}$

There are some considerations to form new Indonesia's Criminal Code, such as philosophical consideration, juridical consideration, and sociological consideration. Based on philosophical consideration, colonial regulations are said to be no longer suitable and not consistent with value and soul of Pancasila. Based juridical consideration, there are also some inconsistencies between substance in the code with Indonesia's Constitution's substance. Indonesia's Constitution guarantees constitutional rights which now well known as Human Rights. It's proved by fact, in the old code, there are no provisions concerning violation of human rights. Besides, in the draft of new code, death penalty no longer placed as main punishment, but being placed as alternative punishment to protect society's sense of justice. Based on sociological consideration, society's development which followed by development of crimes, need to be balanced with the existence of sufficient law means, including regulations about what are prohibited and the punishment follows.

Basically criminal law reform in Indonesia has not yet lead to development of a modern and comprehensive legal basis. Nevertheless during the establishment of rules of criminal law is done by way of a patchwork, so the shape is varied, depending on what is stipulated by the regulations. ${ }^{18}$ Furthermore not to mention that the renewal process is done partially and not thorough, therefore could not solve new problems. The concequence are many laws and regulations that are sectoral and are not consolidated in the Book of the National Criminal Law.

Renewal of the Criminal Code can use two methods. First, the partial renewal or partial codification, by replacing part after part of the criminal code. Second, full codification, thorough renewal by replacing total codification of

17 Nella Sumika Putri, "Perkembangan Asas-asas Hukum Pidana Melalui Perundangundangan Pidana di luar KUHP dan Dampaknya Terhadap Pembaharuan Hukum Pidana Indonesia,"in Hukum Pidana Indonesia-Perkembangan dan Pembaharuan, ed. Sigid Suseno, Nella Sumika Putri(Bandung: Remaja Rosdakarya,2013), p. 311.

${ }^{18}$ ELSAM, op. cit., p. 6 
the criminal law. ${ }^{19}$ At the moment, the Government has the intention of going with the full codification method. The Government wants to cover the entire article on criminal deeds, which already exists in various laws. On the other hand, the Government is also encouraging the birth of new criminal deeds in a number of regulations outside the Criminal Code. ${ }^{20}$

Until now, several criminal deeds are regulated inside and outside the code. Regulating criminal deeds outside the code are based on some considerations like: development of crimes, society's need, and international society's force. In fact, not only the amount of crimes increases, but there are also changes and development about criminal law principles which significantly being presented by those statutes, in material and formal criminal law concept. ${ }^{21}$

The statement above shows that regulations outside the code are exactly needed. Even Indonesia Criminal Code that now prevailed has a provision about the relationship between regulation inside and outside the code in Article 103:

The provisions of the first eight Chapters of this Book shall also apply to facts on which other statutory provisions impose punishment, unless determined otherwise by statute.

The provision above implied Lex specialis derogat legi generalis principle which means criminal regulations outside the code will be applied to facts. That provision only talks about the first eight chapters of the first book of the code, but the problem is what if the provisions in the second book of the code or in the draft of Indonesia Criminal Code, differently regulates the same facts. Based on our opinion, there are three fundamental principles:

1. A provision is not allowed to be in conflict with provision(s) in higher position. (Lex superior derogat legi inferiori), so that in different position, higher statute will applied to fact.

2. In case both provisions in same position are in conflict, principle Lex specialis derogat legi generalis and Lex posterior derogat legi priori have to be noticed.

We will also face problems, when if there is a new statute, and it consists of general provisions. It will be difficult to decide which will be applied on facts. To solve that problem, we also have to see how the Draft of Indonesia's Criminal Code regulates those matters.

Transitional Rules regulates:

Article 760 Draft of Indonesia Criminal Code:

When this Code is prevailed:

19 , 2 (2013), p.1.A. A. Ngurah Oka Yudistira Darmadi, Konsep Pembaharuan Pemidanaan dalam Rancangan KUHP, “Jurnal Magister Hukum Udayana”, Vol. 2, No. 2, (2013), p. 1.

${ }^{20}$ Indonesia Centre for Law \& Policies Studies, "Government Submits Academic Paper and Criminal Code Bill to House of Representatives," Indonesia Law Reform Weekly Digest, Indonesia, (June 12, 2015)

${ }^{21}$ Nella Sumika Putri,op. cit., p. 308. 
a. Penal regulation, as long as regarding with general criminal deeds, has to be done as part of this Code's materials.

b. Provision in part (a), directly constitute codification system and unification of National Criminal Law.

Article 760 Draft of Indonesia Criminal Code:

When this Code is prevailed:

a. every provisions regarding criminal deeds outside the code, are stated to still be in forced as long as the substances are not regulated in this Code

b. if there are difference between provisions in this code and in others regulations :

1. the applicable provision is one which brings benefit for the offenders;

2. if after penal verdict has permanently in force, the deeds has stated to be no longer be unlawful act, the execution of penal verdict removed; or

3. If after penal verdict has permanently in force, the punishment of that deed is less undemanding based on other regulations or this code, the execution of penal verdict will be adapted with terms of penal punishment based on those statutes.

c. Provisions on part (a) and (b), also applied for Local regulations which consist criminal provisions.

The terms above, which have been given by lawmakers for us to face conflicts of law applications, are only to apply provision which brings benefits to the offender. It can cause:

1. If the new code have more oppressive punishment, that punishment will be useless because it can't be applied on a concrete fact, because punishment that must be applied is the more undemanding one.

2. Public Prosecutors practically will charge all relevant provisions to the offender in variations of form (alternative or subsidiary), to avoid offenders acquitted from charges. It makes the heavier burden of proof in Prosecutor's sides.

3. In case the fact is specific, the existence of regulations outside the codes is still in demand.

\section{Conclusions and Recommendations}

\section{Conclusions}

Based on the explanations above, we like to conclude that:

1. Criminal deeds which have been regulated in specific regulations don't need to be re regulated by the code, because it will cause overlapping and confusing in law enforcement process. Specific regulations outside the code are more able to regulate a criminal deed in more comprehensive way, also with specific procedural regulations (if necessary).

2. If the Draft of Indonesia Criminal Code were prevailed and consists of all the provisions regarding specific criminal deeds, the way to harmonize 
those regulations will be based on transitional rules which said that the applicable provision is one which brings benefit for the offender.

\section{Recommendations}

We recommend that lawmakers reconsider the urgency of regulating specific crimes (which have already regulated outside the code). If there areunregulated matters, it will be easier to change a specific statute, than to regulate it in a codification. 


\section{References}

\section{Books}

American Bar Association. Access to Justice Assessment for Indonesia South Sulawesi Province. Washington D. C.: American Bar Association, 2012.

Atmasasmita, Romli. "Politik Hukum Pidana dalam Pembangunan Nasional." In Hukum Pidana Indonesia: Perkembangan dan Pembaharuan. Eds. Sigid Suseno, Nella Sumika Putri. Bandung: Remaja Rosdakarya, 2013.

ELSAM. Tinjauan Umum terhadap Rancangan Kitab Undang-undang Hukum Pidana (KUHP). Jakarta: ELSAM, 2005.

Ibrahim, Johnny.Teori dan Metodologi Penelitian Hukum Normatif. Malang: Bayumedia Publishing, 2006.

Muladi.Bunga Rampai Hukum Pidana. Bandung: Alumni,2007.

National Law Development Agency of the Ministry of Justice and Human Rights, the Republic of Indonesia. Academic Draft of the Book of Criminal Law Draft (KUHP, 2015). Jakarta: Republic of Indonesia, 2015.

Putri, Nella Sumika."Perkembangan Asas-asas Hukum Pidana Melalui Perundang-undangan Pidana di luar KUHP dan Dampaknya Terhadap Pembaharuan Hukum Pidana Indonesia." dalam Buku Hukum Pidana Indonesia-Perkembangan dan Pembaharuan. Bandung: Remaja Rosdakarya, 2013.

Reksodiputro, Mardjono.Menyelaraskan Pembaharuan Hukum. Jakarta:Komisi Hukum Nasional, 2009.

Soekanto, Soerjono.Pengantar Penelitian Hukum.Jakarta:UI Press, 1986.

Soemitro,Ronny Hanitijo. Metodologi Penelitian Hukum. Jakarta:Ghalia Indonesia, 1982.

\section{Articles}

Darmadi, A.A Ngurah Oka Yudistira. "Konsep Pembaharuan Pemidanaan dalam Rancangan KUHP.” Jurnal Magister Hukum Udayana, Vol. 2, no. 2, (2013).

Indonesia Centre for Law \& Policies Studies, Government Submits Academic Paper and Criminal Code Bill to House of Representatives. Indonesia 
Law Reform Weekly Digest, Indonesia, June 12. Jakarta: Indonesia Centre for Law \& Policies Studies, 2015.

Renggong, Ruslan."Reform of Criminal law and Implications for Law Enforcement in Indonesia". Journal of Studies in Social Sciences, Vol. 8, No. 2, (2014).

United Nations Rule of Law. "Report of the Secretary-Genral: The Rule of Law and Transitional Justice in Conflict and Post-Conflict Societies, quotes in What is the Rule of Law?". $<$ http://unrol.org/article.aspx?article_id=3>, accessed October 15, 2015.

\section{Law and Statutes}

Indonesia Criminal Code

Draft of Indonesia Criminal Code 